\title{
Building Bridges Across Frames?
}

\section{A Meta-Evaluation of Dutch Integration Policy}

\author{
P. W. A. SCHOLTEN Sociology of Governance, University of \\ Twente \\ F. K. M. VAN NISPEN Public Administration, Erasmus University \\ Rotterdam
}

\begin{abstract}
The integration of immigrants is an intractable policy controversy in Dutch politics: the Blok Committee was established by Parliament to offer a resolution. However, its evaluation study 'Building Bridges', itself became controversial. This paper asks: Why did the policy evaluation of the Blok Committee become so fiercely contested? We argue that the debate on immigrant integration can be characterized by frame-conflict: there were fundamental differences in how immigrant integration was defined and normatively interpreted by actors. The resolution of such ill-structured problems requires the critical articulation of multiple and conflicting frames. In situations of intractable policy controversies, policy evaluation should reach beyond mere technical and contextual levels to include systemic and ideological discourse. Policy evaluation can thereby focus more on utilization and contribute to the resolution of intractable policy controversies by building bridges among conflicting frames.
\end{abstract}

Key words: policy evaluation, policy controversies, frame reflection, immigrant integration policy

\section{Introduction}

The integration of immigrants has evolved into one of the most salient policy controversies in the Netherlands. The government policy has changed dramatically at several points during the past decades. Yet, it continues to trigger controversy over basic questions on how to define integration, how to determine the target groups and how to value multiculturalism. After the turn of the millennium, policy has been changing dramatically once more. Fuelled by debate on the 'multicultural tragedy' in 2000, the public unrest that followed the terrorist attacks against the US on II September, 200I, and the rise of the populist politician Pim Fortuyn who was murdered on the eve of national 
elections (2002), the controversy returned to the political agenda. Many political parties now denounced the policies that had been conducted thus far as a failure. In this explosive setting, parliament established an ad hoc committee, the Blok Committee (named after its chairman S. A. Blok) to find out why the integration policy had become a failure and to offer proposals for a more successful integration policy. Politically, the Committee membership reflected the major Dutch parties.

In its report, 'Building Bridges,' the committee came up with some contradictory findings. To a large extent, its findings were based on a fact-finding study commissioned to the Verwey-Jonker Institute to scrutinize the existing literature on integration policy. The findings of the institute challenged the common opinion that the integration policy was a failure, and instead considered it relatively successful, especially in supposed key domains such as education and labour. The Blok Committee deliberated on the study's findings and held public hearings and interviews with experts in the field. It concluded that immigrant integration had indeed been a 'total or partial success' (Blok 2004: I05). The evidence of progress in education and labour supported this conclusion, although the committee claimed that this success was due to the efforts of involved stakeholders rather than the policy itself.

These findings contrasted sharply with the negative tone of public and political debate on immigrant integration. The committee was criticized for introducing a bias in its findings by focusing on socio-economic facets and disregarding cultural and religious aspects of immigrant integration. The committee's evaluation of immigrant integration initiated deeper disagreements about the nature of immigrant integration.

Rather than resolving the ongoing controversies, the committee instead became the target of controversy. Although many of its instrumental recommendations were eventually adopted by parliament, but its most fundamental conclusion about the success of the integration process was widely and often strongly rejected. Disputes emerged in the midst of the committee proceedings about the members' supposed bias and a conflict of interest with the institute that commissioned the study. Specifically, debate emerged about the choice to ask the experts of the Verwey-Jonker Institute to evaluate this policy, as these experts would have been involved in policy-making. Vice-chair Lazrak argued that too much policymaking power had been delegated to scientific experts, who would have been too policy-oriented and biased to a multiculturalist model of integration. Furthermore, leading politicians rejected the committee findings, because they were disappointed that the committee had not looked at the cultural problems that were now so central to the ongoing debate.

In this article we provide a meta-evaluation of the work of the Blok Committee's evaluation of an intractable policy controversy. Intractable 
policy controversies involve issues where the problem definition or 'framing' is inherently contested (Rein and Schön r994, I996). Thus, there is no agreement about what the problem actually is as well as what should be done about it. Immigrant integration has evolved into an intractable policy controversy.

We will argue that the design of the evaluation study, focusing on technical verification and to a lesser degree situational validation was not appropriate for resolving the controversies about this ill-structured problem. By focusing on mostly technical questions of whether or not immigrant integration was progressing in specific areas, the committee missed out on an opportunity to reflect on the deeper disagreements about the nature of the immigrant integration issue.

The resolution of such controversies would, according to Rein and Schön (1994), require 'frame reflection' or a critical dialogue between involved actors about how an issue is to be framed. Policy evaluation can contribute by taking the multiplicity of frames as an object of analysis. This involves reflection on the framing of the integration policy as well as on the frames of involved actors. Instead, the committee seems to have adopted its own frame of immigrant integration, based on a socio-economic perception of immigrant integration that had been dominant in the rg9os. The committee held expert meetings and public hearings, the purpose of which was to test the primary findings from the report of the Verwey-Jonker Institute. Participants were neither addressed as representatives, nor interrogated about the shifts in their frame. Subsequently, the committee's own frame became fiercely contested in public and political debate on immigrant integration.

By studying the relations between the problem context of immigrant integration and the design of the evaluation study, this article will generate insights on the role of policy evaluation in overcoming the 'dialogues of the deaf' that seem to have characterized the relations between policy analysts and policymakers in this domain and, more generally, in intractable policy controversies.

\section{Problem analysis}

Problems come and go in various configurations. A distinction can be made between three types of policy problems: well-structured, moderately structured and ill-structured (Dunn 2004; Hisschemöller and Hoppe i995). Well structured problems are characterized by clarity of the normative perspective and the appropriate policy means and methods. They involve a clear and generally accepted problem framing, and generally remain uncontested in politics. These types of problems 
are often depoliticized and dealt with in a technical, scientific manner. Moderately structured problems involve uncertainty about either the involved norms and values or appropriate means and methods. They trigger political negotiations and bargaining over norms, values and appropriate solutions. Finally, ill-structured or 'wicked' problems involve conflict about problem framing resulting in debate about the normative perspective and uncertainty about appropriate means and methods to reach a solution. They often lead to intractable conflict between actors with different problem frames who fail to understand one another because of their different ways of making sense of a problem.

Ill-structured problems tend to produce 'dialogues of the deaf' that can defy resolution for long periods. They generally involve many actors making different claims about how to frame an issue based on different goals (Dunn 2004: 79-80). To the extent that controversies draw in more and more actors and conflicting frames, they are subject to what has been called the 'law of large solutions' (Wildavsky i979: 63). This means that 'the greater the proportion of the population involved in a policy problem, and the greater the proportion of the policy space occupied by a supposed solution, the harder it is to find a solution that will not become its own worst problem' (ibid). For instance, ill-structured problems tend to be resistant to resolution by examining 'the facts', as actors with different frames tend to select and interpret 'facts' very differently. Also, intractable policy controversies tend to involve problem succession rather than problem resolution. A public policy becomes its own cause as: 'more and more public policy is about coping with consequences of past policies . . . and less and less about events in society' (Wildavsky i979: 4). Problems are not solved - at least not conclusively-but instead create further problems. 'Instead of thinking of permanent solutions we should think of permanent problems in the sense that one problem always succeeds and replaces another' (Wildavsky i979: 5).

A frame involves a cognitive framework 'that governs the subjective meaning we assign to social events' (Goffman, I974, IO-I I). It provides an answer to the question 'what is going on here'. Furthermore, it 'names' the relevant aspects of a problem and 'frames' them into an intelligible account, providing a 'way of selecting, organizing, interpreting, and making sense of a complex reality to provide guideposts for knowing, analyzing, persuading and acting' (Rein and Schön r994: 23). Intractable policy controversies are characterized by a multiplicity of frames (Rein and Schön I996: 240). This can lead to frame-conflicts, or 'struggles over the naming and framing of a policy situation ... (as well as) symbolic contests over the social meaning of an issue domain, where meaning implies not only what is at issue but what is to be done' (Rein and Schön I994: 29). 
Frame conflict constitutes one of the causes of policy failure, especially now that the image of the government as the conductor of an orchestra has been replaced by the government being seen as one of the musicians, albeit an important one (Van Nispen and Ringeling I998: 210). A public policy is seen as the outcome of the interaction of many interdependent actors, each articulating their own policy frame and pursuing their own interest ('t Hart and Kleiboer i995). The art is to reach agreement on a common problem frame and course of action. However, one may question how this can be achieved, as accepted strategies to solve conflicts such as consultation and negotiation do not seem successful in solving controversies when actors do not agree on problem framing. Even research does not work, because intractable controversies are resistant to an appeal to reasons and facts. Efforts to bridge the gap between policy frames have induced a proliferation of research, often leading to a 'battle of analyses' (Klaassen and Van Nispen I996) or 'dueling swords' (Radin 2000: 3I).

Rein and Schön have argued that 'frame-reflection' could provide a way for resolving intractable policy controversies. Whereas frames are usually tacit or 'taken-for-granted', frame reflection requires that frames are made explicit. Also, it requires that actors are willing to reflect critically upon their own frames in terms of internal consistency and consistency in the face of new evidence and 'put themselves in the shoes of others' (Rein and Schön I994: I76). Policy analysis could contribute to the 'situated resolution of controversies' by promoting frame reflection.

\section{Policy evaluation}

How can policy evaluation contribute to frame reflection and the 'situated resolution of controversies'? Patton (I979) has described policy evaluation as a utilization-focused sort of policy analysis. Whereas policy analysis is aimed at enhancing our understanding of policy and explaining policy processes, policy evaluation is a more engaged type of policy analysis, leading to conclusions about what is right and wrong and what could be improved. Policy evaluation is meant to contribute to the resolution of policy problems, for instance by evaluating the effectiveness of government policies, institutional structures and the side-effects of policy.

Guba and Lincoln (i989) argue that policy evaluation can determine the criteria for measuring, describing or judging government policies. With social problems in particular, there will often be no 'point of Archimedes' for deciding objectively what the criteria for evaluation should be. In other words, the criteria depend on the chosen problem frame. In such situations a 'fourth generation' type of evaluation study 
would be best fit (Guba and Lincoln i989), which does not measure, assess or describe policy effects based on specific criteria, but rather tries to negotiate among the claims of various stakeholders who use different criteria. Applying this is what Patton calls 'situational responsiveness' in the context of policy controversies. By adjusting the evaluation design to the problem situation, policy evaluation can be more useful.

The contribution of 'fourth-generation' policy evaluation studies to frame-reflection can be illustrated by connecting Rein and Schön's ideas about frame reflection to Fischer's ideas about the four levels of analysis in policy evaluation (Fischer I995, 2003). He goes beyond technical levels of measuring and assessing policy effectiveness, to more fundamental questions concerning situational validation, system vindication and social choice:

(I) Technical verification involves a rather technical way of measuring and verifying whether a policy does what it promised. For instance, did employment measures for immigrants lead to the predicted decrease of unemployment. Or did voting rights for immigrants lead to more political participation?

(2) Situational validation analyses the policy effect on a particular problem situation, but still imposes specific criteria on a problem situation. These criteria are based on the problem definition of a policy. For instance, when integration is defined through equal social-economic participation, policies can be evaluated based on the extent that the level of social-economic participation amongst immigrants approaches the average level. Policies can, however, have adverse effects that negatively affect a problem situation even though individual policy programs are effective.

(3) System vindication requires that the relation between a specific policy and general societal institutions be made explicit. It asks what does a policy such as integration mean for society's central institutions such as the welfare state? Does it erode or sustain the required solidarity? How does it relate to the national economy; are immigration and integration a liability or an economic asset?

(4) Social choice delves deeper in frame conflicts to the level of ideological discourse. It focuses on the paradigm of society involved in a particular policy frame. For instance, to what extent does the integration policy value equality and liberty? Or, how does it value cultural diversity and social-economic differences?

In this article, we examine the degree to which the evaluation study by the Blok Committee managed to contribute to the 'situated resolution' of the controversy around Dutch immigrant integration policy. 
Immigrant integration as an intractable policy controversy

Dutch immigrant integration policy was framed and reframed several times (Entzinger 2005; Scholten 2007), since a policy for the integration of immigrants was developed in the early ig8os. Immigration to the Netherlands had increased since the I950s, first with colonial migration from former Dutch colonies (Surinam, Antilleans, repatriates from the former Dutch East Indies) and later with the immigration of foreign workers from Mediterranean countries (Greece, Yugoslavia, Spain, Italy, Turkey, Morocco). Most were perceived as temporary migrants, as international commuters or guest workers. Policy toward these temporary migrants was mainly group-specific and aimed at preservation of their cultural identities so as not to hamper eventual return to their home countries. Hence, this policy of integration with retention of cultural identity is often described as a 'two-tracks policy' (Entzinger, I984). It was based on a broad political consensus that the Netherlands was not and should not be a country of immigrant integration, therefore no integration policy was required.

By the end of the I97os, tension between the norm of not being a country of immigration and ongoing immigration became increasingly visible A series of terrorist acts by members of an immigrant group, the Moluccans, triggered attention to the weak social position of these 'temporary' immigrants. As a result, immigrants were reframed and renamed as permanent cultural or ethnic minorities within Dutch society. Whereas in several other countries immigrants were defined by racial origin, in the Netherlands they were instead defined by ethnic and cultural origin (cultural non-conformity) and their relatively weak socioeconomic positions (Rath, 200I). A Minorities Policy was developed that was mainly directed at cultural emancipation of these minorities and improving their social-economic positions. Also, the image of Dutch society was reframed as a multi-ethnic or multicultural society in which members of minorities and minorities as groups should have an equal position. The scope of debate about immigrant integration remained restricted, especially to a limited circle of scientific experts and ethnic elites (Guiraudon I998, 2000). In the political arena, there was a norm not to politicize this issue, in part out of fear of benefiting anti-immigrant parties that wished to further their interests based purely on race. As a result of further immigration, The Minorities Policy was reframed once again about a decade later, a deterioration of the socio-economic position of various minority groups, and second thoughts about the image of the Netherlands as a multicultural society. A broad national minorities debate took place, which appeared to waken a 'silent majority' that had been wary of multiculturalism but previously lacked a platform to speak 
out (Entzinger 2003). Also, immigrant integration became more politicized, with various politicians now openly calling for a tougher approach to immigrant integration. The Liberal Party played a leading role in this minorities debate and in subsequent policy changes after being involved in a new broader left-right government coalition in I994. The positive attitude toward cultural diversity disappeared and more stress was put on the civic rights and duties of immigrants to integrate into and participate in Dutch society. Prins (1997) describes this discourse as 'new realism,' which called upon immigrants to fulfil their civic responsibilities as native Dutch citizens do. Policy was reframed into an 'Integration Policy', which focused not on specific ethnic minority groups but rather on individual allochthonous (those not from here). The goal of integration was to promote their socio-economic participation (Scientific Council for Government Policy, I989). The perspective of a multicultural society was replaced by that of a viable welfare state that required immigrants to be able to stand on their own feet.

Immigrant integration returned to the political agenda, triggered by national and international developments, such as the rise of a populist politician in Dutch politics and the i september attacks on the US. In 2002, the centre-right government coalition defined immigrant integration as one of its top priorities. Attention was drawn increasingly to the social-cultural dimension of immigrant integration. Also, the tone toward cultural diversity became increasingly negative, it was perceived as a problem rather than condition for integration. Cultural adaptation of immigrants became one of the central objectives of an 'Integration Policy New Style.' More than just calling upon good citizenship for immigrants, this policy was to call upon common citizenship of all newcomers, involving the acceptance of the basic values and norms of Dutch society. The issue of immigrant integration was now connected to larger concerns about national identity in an era of globalisation and international migration.

These frame shifts in Dutch immigrant integration policy over the past three to four decades are summarized in Table $\mathrm{I}$.

\section{The Blok Committee}

\section{Mission}

Against the background of the frame-shift, to an Integration Policy New Style that parliament called for an investigation of why integration policy had such limited success. Since the I970s, policy had already been declared a failure several times, because it had underestimated the permanent nature of immigration, focused too much on cultural 


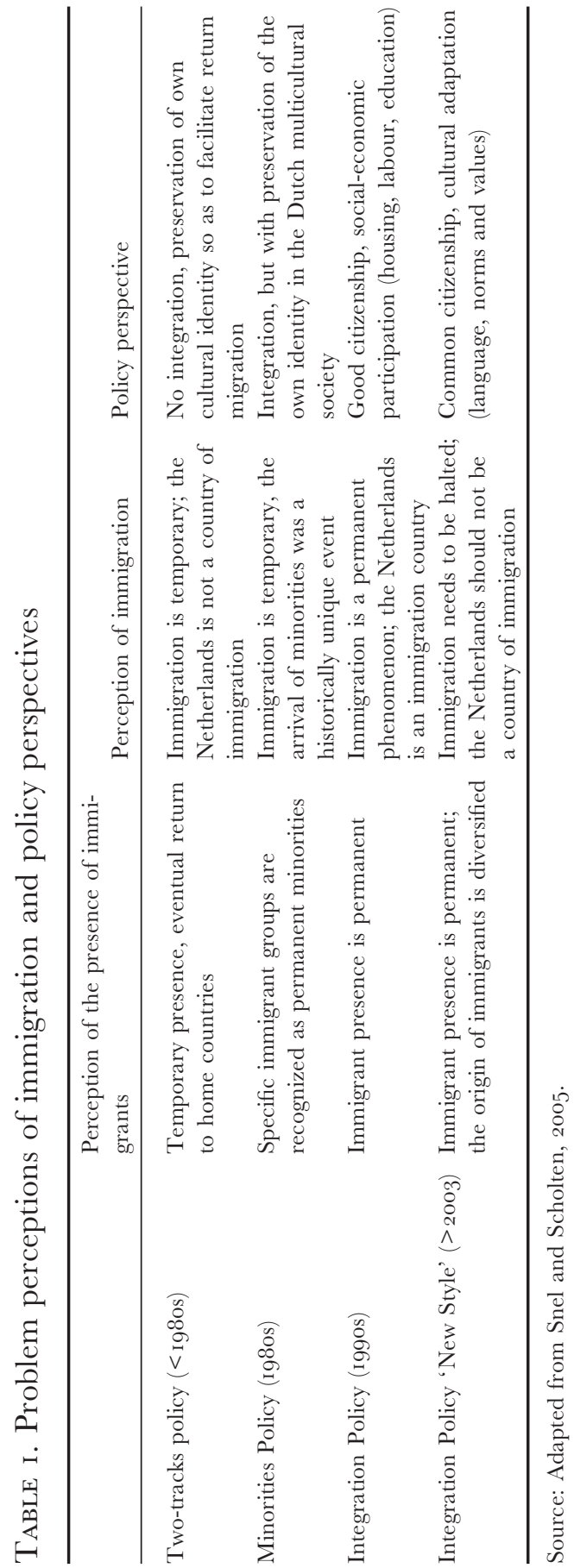


emancipation, did not achieve equal participation of immigrants, or failed to bring about cultural adaptation of immigrants. The failure of the integration policy even became a central topic in parliamentary elections in 2002, causing a dramatic change in political relations as a new populist party became the second-largest party and was included in a new government coalition.

The Dutch parliament has a constitutional right to establish parliamentary investigations and inquiries with more formal powers. In the case of immigrant integration, parliament found it sufficient to establish an ad hoc investigative committee with representatives from political parties, sufficiently broad to support inter-party consensus. The committees are supported by a Research and Verification Office of parliament that can commission research from external institutes.

The motion parliament adopted for establishing this research committee stated:

' the integration policy has thus far been insufficiently successful, observing that it would be desirable to evaluate what have been the causes of this, observing that such a research could provide the building blocks for the formulation of a new integration policy, parliament decides to establish a parliamentary research committee on the integration policy.' (Parliamentary Documents, TK 2002-2003, 2860o, nr. 24).

Following the broad acceptance of this motion, a working group was established to prepare for the parliamentary investigation. It reformulated the research question to be broader than the initial motion. It allowed for more open conclusions concerning policy failure or success and made the evaluation of policy success or failure a part of the research problem. The aim was to enable parliament to assess the integration policy of the previous decades in various domains. The domains selected as relevant included housing and recreation, income and labour, and education. The assignment to the research committee was eventually formulated as follows:

'To enable the Second House of Parliament to evaluate the integration policy of Dutch government over the past 30 years, to evaluate the aimed effects and factual results of this policy and to evaluate the coherence of policy on various policy terrains. Moreover, the research should provide building blocks for the integration policy to come.' (Parliamentary Documents, TK 2002-2003, 28689, nr. I).

The temporary committee had to address the following questions: What integration policy has been conducted in The Netherlands over the past 30 years? What were the goals and results of this policy in important areas such as housing and recreation, income and labour, and education? Has there been a consistent and coherent integration policy in the various domains? To what extent can this policy, given its goals, be qualified as 
successful? Are there experiences in foreign cities with the integration policy from which our country can learn?'

The task description included an explicit reference that it should provide building blocks for a future integration policy. This underlines the political importance of the parliamentary initiative, which clearly ventured beyond the traditional controlling and fact-finding role of parliament. The study of the Blok committee can be characterized as utilization-focused. The work did not stop with an explanation of what happened in the past. The outcome had to be relevant for the design of the integration policy for the near future.

The committee had representatives from political parties with different views on immigrant integration. Besides the three main political parties, the Liberal Party (VVD), Christian-Democrats (CDA) and Social-Democrats $(\mathrm{PvdA})$, the committee also included representatives from the progressive Green Left party, from the Socialist Party that had taken the initiative for the committee, and the Pim Fortuyn Party that had been established after the rise of Pim Fortuyn on the political arena several years before.

\section{Design of the evaluation study}

The first step of the evaluation committee was to commission an extensive study of available literature and the progress of the integration process. This study had to provide a provisional answer to all five of the above research questions, factual information and address more normative issues such as goal-attainment and effectiveness, and had to be completed in no more than two and a half months. It was commissioned from a commercial research institute, the Verwey-Jonker Institute, selected because of its tenor expertise in this area. Also, it was argued that this institute was not involved in the design of the policy under scrutiny (Blok 2004: 17). Several other experts and institutes had rejected the Blok Committee's request for an investigation because they felt that they had been too strongly involved in policy developments themselves or because they felt that the time period allowed for the research was too limited for any significant research. For the Verwey-Jonker Institute, an important condition for accepting the task was that there was no prior conclusion about policy failure or success:

Before we accepted the assignment, we wanted clarity about the formulation of the research problem. There was a (...) motion in which Parliament already stated that the integration policy had failed. Subsequently, a working group worked on that. We only accepted the assignment after it became evident that this working group had already formulated a broader research question, that is: what is there to be said about the success or failure of policy and what does that say over the 
integration of immigrants. (Director of VWJ Institute in De Hart and Prins 2005: I82).

Based on the desk research done by the Verwey-Jonker Institute, the Blok committee commissioned six more secondary studies on the labour market position of immigrants; the role of self-help organisations; welfare organisations and interest groups; the emancipation of girls and women; policy objectives for education; foreign cities' experiences with immigrant integration; and the role of governments in immigrants' countries of origin. The additional studies were done by various commercial research institutes, including the Verwey-Jonker Institute.

In addition, the Blok Committee held a series of closed and open interviews with persons that had been involved in the national and local integration policy over the past decades. The aim was to 'test the findings from the sources study and the opinions of various actors, (to) enhance knowledge and insight in the matter concerned (and to) select persons that would be invited for the open meetings' (Blok 2004: I9-24). In total, Io3 closed meetings were held with I45 persons. The primary function of the open meetings with a very large range of actors, 86 (open) meetings with I42 persons, was to 'test the findings of the preparatory research in public' (ibid). The interviewees included former ministers, civil servants from the local and national level, scientists, representatives from minority organisations and also successful immigrant women.

Finally, the Blok Committee was the first parliamentary committee going to cities to hold public hearings for all those interested in having their voice heard. Four large and mid-sized cities were selected across the country (Amsterdam, Rotterdam, Tilburg and Deventer), and participation was open. The aim was to provide a voice to people in the street. It is important to note, that these people were not consulted as representatives of their minority group.

\section{Findings: The Verwey-Fonker Institute}

The Verwey-Jonker Institute (2004: I96) concluded that the integration policy had been 'relatively successful'. It based this conclusion on its own framing of immigrant integration, as manifested by its claim that 'success in one domain can be of higher importance that in others' (ibid: I96). In particular, the 'success in the domain of education appears (to be) the key for the further success of the integration process', making the results in this domain are of 'extra importance'. Moreover, the institute concluded that 'part of the intended goals have been realised ... especially in the domain of education', as well as housing, whereas for income and labour 'have been less achieved' (ibid.). 
The Verwey-Jonker Institute also put this conclusion in a broader context by critically reflecting on this frame. It claimed that in terms of social-cultural integration the integration policy had been less successful, due to inconsistency of policy. The Institute concluded that "the statement in the parliamentary motion that policy has been insufficiently successful appears (to be) ... partially correct; in several socio-economic areas and especially in the cultural domain there is a certain gap between formulated objectives and results that have been attained thus far' (Verwey-Jonker Institute 2004: 197). With regard to the growing focus on the cultural domain in the recent Integration Policy New Style, the Institute warned against an 'anachronistic evaluation' of policy results based only on recent policy objectives. 'Results are lagging mainly in areas where only recently new and sharper goals have been formulated' (ibid). Here the Verwey-Jonker Institute seems to have anticipated the frame-conflict to come. Moreover, it questioned 'in the context of recent political turbulence, whether the goals have been always formulated sufficiently broadly in the past'. Policy had focused too narrowly on the position of immigrants, regardless of the consequences for the native population. In this respect, it considered 'the problems of the multicultural society ... far from resolved' (ibid).

Moreover, the Verwey-Jonker Institute was critical about the feasibility of immigrant integration as a policy. It observed that policy goals had been too ambitious, and criticism about the feasibility of social problems would seem to have passed over this policy domain. Politicians' common reaction to the failure of the integration policy would have been 'more of the same'. More generally, there seemed to be a paradox: ambitions and expectations increased, whereas the policy impact in many areas decreased.

\section{Findings: The Blok Committee}

The final conclusion of the Blok Committee deviated slightly from the formulation of the conclusions of the Verwey-Jonker Institute:

The integration of many immigrants has been a total or partial success, and ... this is quite an achievement, for the involved immigrant citizens as well as for the host society (Blok 2004: 105) (emphasis added).

The Blok Committee appears to have focused on socio-economic participation in general, and the role of language and the role of values and norms of society in particular. The committee formulated its own definition of integration, which provided the basis for its conclusion that the integration had been a total or partial success (Blok 2004: I05):

A person or a group is integrated in Dutch society when they have an equal legal position, equal social-economic participation, knowledge of Dutch language and 
when common values, norms and patterns of behaviour are being respected. Integration is a two-sided process; on the one hand, newcomers are expected to be willing to integrate, on the other hand Dutch society must make this integration possible.

The committee concluded that 'integration rather than the integration policy' has been relatively successful, yet was sceptical of the role of government policy in this success. It observed that although 'in many areas (housing, labour, education, emancipation) results have been achieved, ... causal relations with the general integration policy are difficult to prove' (ibid: 522). The success of the integration policy would also have been affected by general developments in society, and the Blok Committee seemed to endorse with the Verwey-Jonker Institute's observation about a gap between policy goals and the means for achieving these goals.

A closer examination of the findings of the Blok Committee shows that the success of the integration process differs significantly among various domains (Table 2). For instance, in the domain of labour and income the goal of proportional representation was not achieved, and in the domain of housing problems, spatial concentration is observed. Also, women's emancipation was ignored too long, and there was no evidence of a positive contribution of immigrant self-help organisations to the integration process. The Blok Committee gave no importance to the reflection of the Verwey-Jonker Institute on the cultural dimension.

\section{From cure to object of controversy}

Although the parliamentary research committee was established to find a way out of the intractable controversy over immigrant integration, long before it could present its findings it became an object of controversy. Even before findings were released the representative of the Socialist Party went public with severe criticism. Even though the Socialist Party had taken the first initiative for establishing the committee, he quit it, partly under pressure from his own party. Consequently, the committee's proceedings became subject to open debate and immense pressures of politicization.

A major topic in the debate on the committee's proceedings, concerned the committee's decision to request a study from the Verwey-Jonker Institute. The Socialist Party member claimed that scientific experts from this institute had been too closely involved with policy development in the past. The expert authority of this institute was further questioned because of the alleged political connections of one of its directors and to authors of the study for the Blok Committee. This 


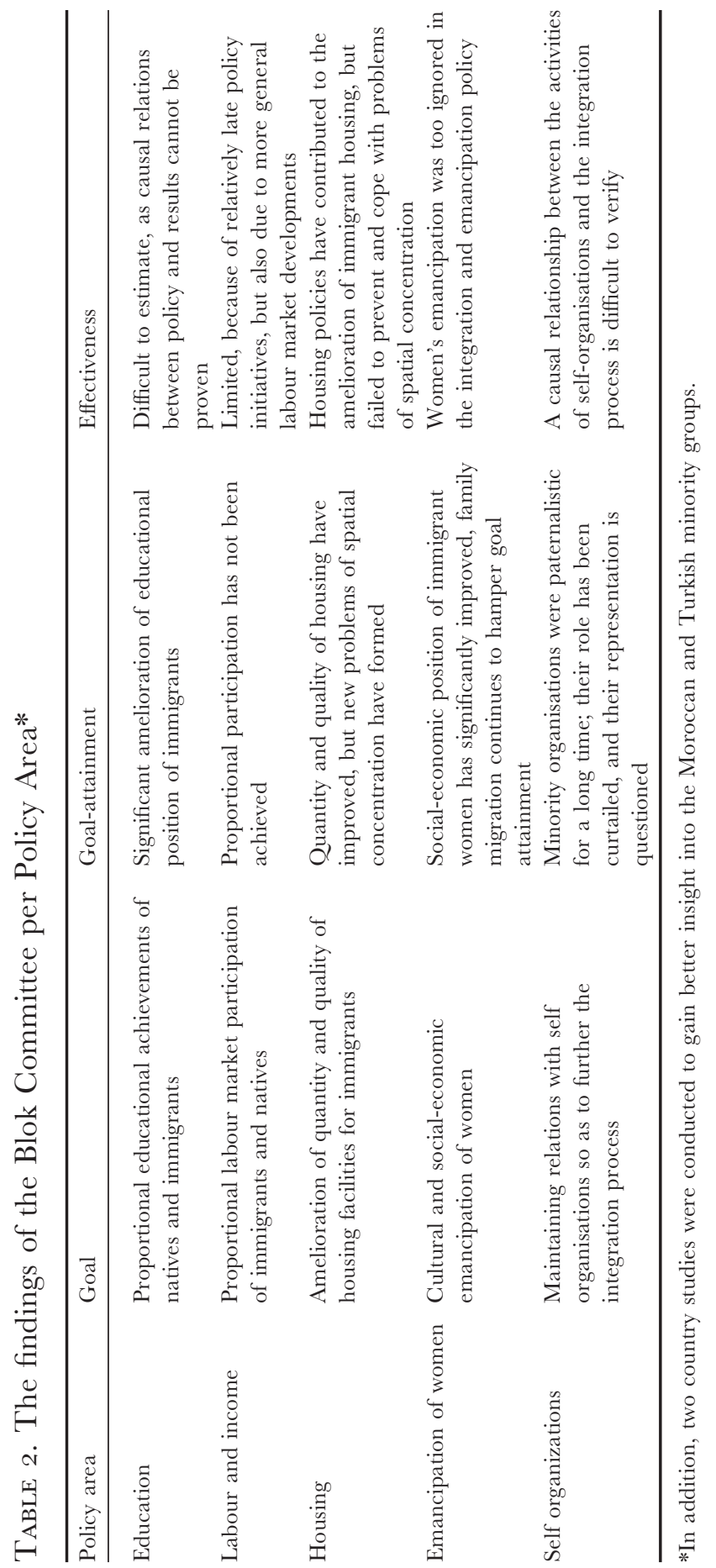


expert was involved with the leftist Green Party, which was now severely criticized because of its multiculturalist bias and support of political correctness and taboos that were seen as some of the main causes of policy failure.

The criticism focused on the Blok Committee's conclusion that the integration policy had been relatively successful, based on its analysis of the social position of immigrants in key areas such as education, labour and housing. Surprisingly little attention was paid to the more critical conclusions about the cultural integration of immigrants, that did fit the emerging mode of discourse (A director of the VWJ Institute commented [cit. in De Hart and Prins, 2005: I85]).

A researcher must always have a particular relation to the dominant discourse.... Only if you discuss really cutting problems will people be willing to read the rest of the report. In the study for the Blok Committee we have observed spectacular progress of immigrants in the domains of housing, labour and education. ... But we also concluded that the integration as a whole cannot be defined as successful. ... Without the Blok Committee asking us for it, we have put these problems on the agenda, also to make that bridge to the broader debate. Nonetheless, we were attacked most on the positive part of our conclusion. Apparently, one is quickly too optimistic in these gloomy times.

As the debate expanded, criticism turned to the entanglement between scientific experts and policymakers in this domain, and to their alleged multiculturalist bias (see Scholten 2007). In the media attention turned to a lack of political vision on immigrant integration, and to a supposed delegation developing a focus on networks of experts whilst ignoring the 'voice from the street'. Also, the Socialist former committee member expressed criticism over what he saw as an overemphasis on socio-economic issues instead of cultural issues (Huygen 2003).

Broad public and political attention to the activities of the Blok Committee and pressure from parliament prompted the committee to make public the report from the Verwey-Jonker Institute. This again led to debate about its conclusion that the integration had been relatively successful, and triggered the indignation of various actors who found this conclusion impossible. Before the final committee report was published, representatives from the two parties in government had decided that regardless of what the committee concluded, they would stick to their view that the integration policy had failed (Moerland 2004).

In parliamentary hearings, debate emerged about whether the Blok Committee had 'measured' what it set out to measure. This debate focused on the definition of integration, and it questioned the usefulness of an evaluation study when neither a consensus on the problem definition nor the problem framing existed. According to a representative 
of one of the parties in government; "there has never been a consensus on a definition of the word integration (and therefore,) parliament has given the research committee an assignment that was too vague' (Parliamentary Treaties, TK 2004, 63-4IO2). In fact, various parties, with different problem frames, pointed to supposed 'blind spots' in the committee report, such as the role of religion in general and Islam in particular, criminality, and the lack of attention for general cultural issues. In addition, a representative from the party that had taken the initiative for this committee asked how the committee could have come to its relatively positive conclusions about integration policy when it had been given the assignment to investigate why policy had failed (Parliamentary Treaties, TK 2004, 63-4I27). In the parliamentary hearings following the committee report, criticism with regard to the choice for the Verwey-Jonker Institute continued. This criticism was extended to the composition of the committee itself, as one of the committee members had been State Secretary of Education and was thus involved in evaluating to what extent her own policies had been successful.

In spite of this criticism, several parties positively evaluated the debate triggered by the committee report, believing that the debate would help move politics 'beyond the phase of denial' and establish a general feeling that 'disinterestedness and lack of commitment should now belong to the past' (Parliamentary Treaties, TK 2004, 92-5932). Indeed, following the committee report, most political parties presented papers in which they developed their positions on immigrant integration. Others argued that instead of the 'political correctness' of the past that led to ignoring problems of immigration and integration, a new sort of political correctness would take its place, which is to always claim that policy has been a failure. This would evolve into the taboo of 'saying something positively about the integration of immigrants, which would be naïve or which would mean ignoring the problems' (Parliamentary Treaties, TK 2004, 63-4II2). In this respect, it would have contributed to the radicalization of a new realist discourse or a sort of hyperrealism, 'in which the courage of speaking freely about specific problems and solutions became simply the courage to speak freely itself' (Prins 2002: 252).

Government, however, dismissed the Blok Committee's main conclusion that the integration was a partial success, in a rather cryptic formulation:

'It is indeed so that the integration of many immigrants has totally or partially succeeded. This leaves open the exact meaning of 'partially successful'. It also implies that for other immigrants integration has not been either totally successful or totally a failure. The latter conclusion is decisive for the Cabinet' (Parliamentary Documents, TK 2003-2004, 28689, nr.I7). 
Eventually, parliament accepted 25 of the 27 committee conclusions. The controversies did not prevent the government from using the Blok Committee's conclusions and recommendations to formulate its Integration Policy New Style, although the Minister of Integration claimed that the formulation of this new integration policy had begun before the Blok Committee published its final report. However, on the level of policy framing, the arguments used by the Blok Committee for claiming the total or partial success of the Integration Policy, remained rejected.

\section{Meta-evaluation}

What went wrong? Why did the Blok Committee fail to build bridges amongst the various frames involved in this intractable policy controversy? Why did it fail to bring about a process of frame reflection? Why did it become object of controversy rather than a cure for the controversies that have haunted this policy domain for decades?

\section{Problem analysis}

The series of frame-shifts that occurred in Dutch immigrant integration policy in the past makes it particularly difficult to evaluate whether policy has been a success or failure. First, the constant reframing of immigrant integration makes it difficult to qualify policy as successful or not. The Blok Committee tried to cope with this problem by formulating its own definition or frame of immigrant integration. In a similar way, the Verwey-Jonker Institute developed its own frame, with education as the key sector in integration. In this respect, one may question if the Blok Committee addressed the correct problem, committing what Howard Raiffa has called the so-called 'error of the third type' (Dunn, 2004; Raiffa, I968: 264). The definition of integration used by the Blok Committee shaped its problem analysis and, consequently, the design and outcome of its evaluation study.

Bias in the background of the Blok Committee members was evident from the start. Although a parliamentary working group had formulated the research questions for the committee as a more open examination of the extent to which policy could be qualified as successful, the assumption that policy had been a failure led to the initiative for this report. Taking into account the controversy about framing, the mission of the Blok Committee can be characterized as impossible.

\section{Goal displacement and problem succession}

This policy domain has gone through three policy cycles in as many decades. In different periods, different frames of immigrant integration 
were adopted and different policy goals were set. These goals reflected various 'frames' of immigrant integration, within a changing political environment in the Netherlands. This created a dilemma for the Verwey-Jonker Institute and the Blok Committee: Upon which policy goals should success or failure be evaluated?

On the one hand, academic or epistemological criteria require the original goal be used to evaluate a policy. On the other hand, the current goals matter as the evaluation is basically utilization-focused. Parliament's objective when establishing the evaluation committee was to provide recommendations for improvement. Evaluation based on particular goals, for instance from a particular period or from another source, might give the wrong impression that a policy is a success or a failure. This seems to be precisely what happened in this case, where immigrant integration policy was evaluated based on goals derived from specific definitions of integration in a context where the policy goals were rapidly changing. Entzinger notes that the rules had been changing while the game was in play (Entzinger 2005).

The Verwey-Jonker Institute did not find a solution to this dilemma. Its conclusions are rather ambivalent. It determined that the outcome of the Dutch integration policy was relatively successful over the last three decades if seen through the lens of the original goals, albeit there was no official goal in the first period. More precisely, the institute concluded that the socio-economic situation of minority groups has improved substantially, though the groups are still lagging behind in comparison with the rest of society. However, the outcome is less positive when the Dutch integration policy is judged against the current goals of the coalition in office. The institute argues that using recent goals would be anachronistic (Verwey-Jonker Institute 2004: 197). The institute's conclusion is supported by former minister Hedy d'Ancona who was responsible for the Dutch integration policy (1989I994). She argued that a historical angle is needed for a fair judgment of the Dutch integration policy. For a long time integration was not even an issue. Only recently did immigrant integration become a problem. In addition, she pointed out inconsistencies: definitions changed constantly, goals were not operational and there was no effective steering in policy practice On top of that, in the r9gos, attention shifted from immigrant integration to social innovation in big cities (Moerland and Santing 2003).

Finally, there is the problem of succession. Not only did policy goals change, but the effects of policies from a particular period were negatively valued in other periods. For instance, the focus on the cultural emancipation of ethnic minorities in the I980s contributed to the minority position of immigrants and hampered the development of their 
citizenship status. As such, the history of Dutch integration policy reveals various instances where policy has become its own cause.

\section{Goal attainment and effectiveness}

The Verwey-Jonker Institute correctly states that it is easier to assess goal attainment than the effectiveness of the instruments requiring, among other things, a quasi-experimental design. The flaws of the design make unclear whether the changes are due to the instruments or to other variables (Verwey-Jonker Institute, 2004: 9). While the partial success of the Dutch integration policy may be due to other variables, the partial failure of the Dutch integration policy may instead be due to countervailing powers. In addition, expectations may have been too high, with overly ambitious or unrealistic goals, which might have been too ambitious and/or not realistic (ibid: ig6). The institute does not take a position in this methodological discussion. No attempt was made to unravel the effects of the Dutch integration policy from changes in the environment. The institute simply concludes that the government played a major role in the outcome of the Dutch integration policy (ibid: I99). However, there is no evidence for this conclusion in the report. A description of the situation ex ante (pretest) never happened, and there was no control group. Therefore, it was impossible to draw conclusions regarding the effects of specific instruments.

Consequently, the institute restricted itself to the plausibility of the results of the Dutch integration policy. Unfortunately, the indicators used for assessing the integration of minority groups were not completely clear and were heavily debated in academia, politics and society. For instance, improvement of the position at the labour market was used as an indicator, but one may question if socio-cultural adaptation was more relevant. At a minimum, a reflection on these goals should have been part of the evaluation.

The institute's explanation for the lack of total success must be sought in the gap between the high expectations articulated in the goals and relatively modest instruments and tools, if not in goal displacement. It would be caused less by the internal inconsistency of policy theory (Verwey-Jonker Institute 2004: 199). The institute highlights the lack of attention to obtain the opinions of the minority groups. The evaluation of the Dutch integration policy was more about their situation rather than the cause of the problems (ibid: 178). As such, it claims that a multi-cultural society would still be distant even though much progress has been made in the last three decades (ibid: I98). 


\section{The design of the study}

When evaluating the design of the Blok evaluation study, it is evident that it remained limited to several specific levels of analysis from Fischer's aforementioned scheme. Its main emphasis was on technical verification and situational validation. As for technical verification, the main aim was to determine what the policy goals were and to what extent these goals were achieved. However, a problem that the committee encountered is that policy goals changed frequently. The discontinuity of policy goals may also mean that policy results that are positively valued in one period may be negatively valued in another. For instance, retention of a group's own cultural identity has been valued very differently in various periods as a condition for return migration, a condition for emancipation in a multicultural society and finally, as an obstacle to cultural adaptation.

As for situational validation, the committee examined to what extent improvements or deterioration was causally related to policy. In various occasions, the committee attributes goal attainment to factors other than policy, such as autonomous developments on the labour market, efforts of immigrants and natives, discrimination, etc. In this context the committee came to the conclusion that the integration process and not the integration policy was relatively successful. However, a problem in this respect is to determine whether an improvement or deterioration in the integration process occurred without a clear definition of integration. The committee solved this problem by formulating its own definition of integration, by which the effectiveness of policy measures over the previous decades could be measured.

The committee gave little attention to ideological choice. It did not reflect upon the broader relation between integration and society, such as the relation to the welfare state, to the Dutch economy or to wider resentment in Dutch society about cultural themes. It did not follow up on a broader reflection that can be found in the Verwey-Jonker report, which questioned whether the definition of the integration problem was sufficiently broad. Also, the committee did not venture into more ideological questions, such as whether the Netherlands was or was not a multicultural society, or whether it should be a country of immigration. Such ideological issues, were however at the centre of public and political debate.

The Blok evaluation was not characterized by what Patton described as 'situational responsiveness'. It did not provide what was required for utilization in the context of a raging controversy. In context of frame controversy, policy evaluation could contribute to the resolution of wicked policy controversies by making the controversy itself the subject of analysis. Instead, the Blok Committee chose to formulate its own policy 
frame, against which to measure the success or failure of government policy. By choosing a frame that stressed language and social-economic participation, it created a mismatch with the frame that had emerged in the preceding years, which instead stressed the cultural dimension. In addition, the committee did not compare its frame to others, but rather asked the independent experts of the Verwey-Jonker Institute to measure the extent to which policy was either a success or failure as judged by its frame. Instead of situational responsiveness, the committee chose situational detachment.

Situational detachment led to what Rein and Schön would have predicted. Various actors re-interpreted the information provided by the Blok Committee from the perspective of their own frames. Based on the same information, they made very different claims, ranging between policy being a complete failure to policy being a complete success. In addition, blind spots were found across the board, based on frames with a different selection of information. For instance, several actors claimed that issues such as criminality, religion and culture had been ignored in the report. Also, the parties in government claimed that the committee ignored the cultural dimension of the integration process, which had just been made central in the Integration Policy New Style. Finally, the authority of the objective experts of the Verwey-Jonker Institute became contested, their status became the object of controversy. In particular, the entanglement of researchers and policy-makers and the alleged bias of researchers toward multiculturalism were questioned.

\section{Conclusion: Missed opportunity for frame reflection?}

Immigrant integration could not be addressed by policy evaluation that ignored its contested nature of contestation involved deeper levels of problem framing, such as systemic and ideological discourse, as well as more technical levels. Instead of building bridges among the various frames involved in this policy controversy, the Blok Committee became part of the controversy.

Situational responsiveness in the context of policy controversy requires frame-critical analysis. Policy evaluation could contribute to the resolution of 'wicked' policy controversies by making the frames involved in the controversy themselves the subject of analysis, including their deeper ideological levels. By explicating the involved competing frames and comparing them to each other as well as to developments in the problem situation and the wider macro-institutional environment, policy evaluation could contribute to frame reflection.

A more effective frame-critical analysis would involve not only questions about whether policy worked and contributed to problem 
resolution (technical verification and situational validation), but also questions as to how policy related to broader societal developments and what the ideological basis of policy was (system vindication and ideological discourse). A broader formulation of the research problem (qualifying policy as either a success or a failure) may have induced frame reflection. However, the formulation of its own definition of integration, the use of interviews mainly for testing observations from the desk research done by the Verwey-Jonker Institute, and the absence of broader reflection on the cultural dimension impeded a frame-critical analysis.

The discontinuity of goals skewed evaluation depending on the goals of a particular time frame. For instance, cultural emancipation was one of the goals of the Minorities Policy in the Ig8os, whereas such emancipation was negatively valued by the Integration Policy in the I99os. In fact, it has been argued that the Minorities Policy had an adverse effect by further strengthening the minority position of immigrants, (Rath, 200I). The Blok Committee 'solved' the problem of shifting goals by formulating its own definition of integration and of the problem situation. In formulating its own definition of integration, the committee ignored the broader relation between integration and society, such as the welfare state, the Dutch economy or the wider resentment in Dutch society. Also, the committee did not venture into more ideological questions, such as whether the Netherlands was a multicultural society or not, or whether it should be a country of immigration. Such ideological issues were, however, at the centre of public and political debate.

\section{REFERENCES}

Blok, S. (Temporary Parliamentary Investigation Committee on the Integration Policy, 2004) Bruggen Bouwen. Eindrapport van de Tijdelijke Parlementaire Onderzoekscommissie Integratiebeleid. The Hague: SDU.

De Hart, B. and Prins, B. (2005) 'Onderzoeker tussen wetenschap en beleid. Rondetafelgesprek', in de Waag op de Nieuwmarkt te Amsterdam, I2 mei 2005. Migrantenstudies, 21, I78-I94.

Dunn, W.N. (2004) Public policy analysis: an introduction, 3rd edn. Upper Saddle River, NJ: Pearson/ Prentice Hall.

Entzinger, H. (I984) Het Minderhedenbeleid. Dilemma's voor de overheid in Nederland en zes andere immigratielanden in Europa. Meppel: Boom.

Entzinger, H. (2003) The Rise and Fall of Multiculturalism: The Case of the Netherlands, in Joppke and Morawska (eds.) Toward Assimilation and Citizenship: Immigrants in Liberal Nation-States. Basingstoke: Palgrave.

Entzinger, H. (2005) Changing the rules while the game is on; From multiculturalism to assimilation in the Netherlands, in Bodemann and Yurkadul (eds.) Migration, Citizenship, Ethnos: Incorporation regimes in Germany, Western Europe and North America. New York: Palgrave Macmillan.

Fischer, F. (I995) Evaluating Public Policy. Chicago: Nelson Hall.

Fischer, F. (2003) Reframing Public Policy: Discursive Politics and Deliberative Practices. Oxford: Oxford University Press.

Goffman E. (I974) Frame Analysis: An Essay on the Organization of Experience. New York: Harper \& Row. Guba, E.G. and Lincoln, Y.S. (I989) Fourth Generation Evaluation. Newbury Park: Sage.

Guiraudon, V. (r998) Citizenship Rights for Non-Citizens: France, Germany and the Netherlands, in Joppke (ed.) Challenge to the Nation-State. Oxford: Oxford University Press. 
Guiraudon, V. (2000) Les politiques d'immigration en Europe: Allemagne, France, Pays-Bas. Paris: L'Harmattan.

Hisschemöller, M. and Hoppe, R. (1995) Coping with Intractable Controversies: the Case for Problem Structuring in Policy Design and Analysis. Knowledge for Policy, 4, 8, 40-70.

Huygen, M. (2003) Visie is uitbesteed aan onderzoekers. SP-Kamerlid Ali Lazrak over marginale rol van politici, NRC Handelsblad 20-9-2003.

Klaassen, H.L. and Van Nispen, F.K.M. (I996) De wildgroei van effectrapportages: een rapportage. Bestuurskunde, 5, 7, 308-3i6.

Moerland, R. and Santing, F. (2003) Politici: integratie niet mislukt, NRC Handelsblad d.d. 23 September 2003 .

Moerland, R. (2004) Integratierapport komt politiek niet uit Een parlementair onderzoek voor het eerst ronduit mislukt, NRC Handelsblad 20-I-2004.

Patton, M.Q. (I979) Utilization-Focused Evaluation. Beverley Hills: Sage.

Penninx, R. (I988) Minderheidsvorming en emancipatie: balans van kennisverwerving ten aanzien van immigranten en woonwagenbewoners I967-I987. Alphen aan den Rijn: Samsom.

Prins, B. (1997) The Standpoint in Question: Situated Knowledges and the Dutch Minorities Discourse. Utrecht: Utrecht University.

Prins, B. (2002) Het lef om taboes te doorbreken. Nieuw realisme in het Nederlandse discours over multiculturalisme. Migrantenstudies, 4, 24I-254.

Radin, B.A. (2000) Beyond Machiavelli: policy analysis comes of age. Washington DC: Georgetown University Press.

Raiffa, H. (I968) Decision analysis: introductory lectures on choices under uncertainty. Reading, MA: Addison-Wesley.

Rath, J. (200I) Research on Immigrant Ethnic Minorities in the Netherlands, in Ratcliffe (ed.) The politics of social science research. Race, ethnicity and social change. New York: Palgrave.

Rein, M. and Schön, D. (I994) Frame Reflection: Toward the Resolution of Intractable Policy Controversies. New York: Basic Books.

Rein, M. and Schön, D. (I996) Frame-Critical Policy Analysis and Frame-Reflective Policy Practice, Knowledge and Policy. The International Journal of Knowledge Transfer and Utilization, 9, I, 85-Io4.

Scholten, P. (2007) Constructing immigrant policies. Research-policy relations and immigrant integration in the Netherlands (1970-2004). PhD Thesis, University of Twente.

Scientific Council for Government Policy (I989) Immigrant Policy. The Hague: SDU.

Snel, E. and Scholten, P. (2005) Van gastarbeiders tot het multiculturele drama: integratie als hardnekkig beleidsprobleem, in Arentsen and Trommel (ed.), Moderniteit en Overheidsbeleid; hardnekkige beleidsproblemen en hun oorzaken. Bussum: Coutinho.

't Hart, P. and Kleiboer, M. (I995) Beedenstrÿd in beleidsvorming. Beleid \& Maatschappij, 22, 5, 3I $5-320$

Van Nispen, F.K.M. and Ringeling, A.B. (I998) On instruments and instrumentality: a critical assessment, in B.G. Peters and F.K.M. van Nispen (eds.) Public Policy Instruments: Evaluating the Tools of Public Administration. Cheltenham: Edward Elgar.

Verwey-Jonker Institute (2004) Bronnenonderzoek. Tijdelijke Commissie Onderzoek Integratiebeleid. The Hague: SDU.

Wildavsky, A. (I979) The art and craft of policy analysis: Speaking truth to power. London: Macmillan. 
P. W. A. SGHOLTEN

University of Twente

Faculty of Management and Governance

P.O. Box 217

7500 AE Enschede, The Netherlands

e-mail:p.w.a.scholten@utwente.nl

F. K. M. VAN NISPEN

Erasmus University Rotterdam

Faculty of Social Sciences

Department of Public Administration

P.O. Box $173^{8}$

300o DR Rotterdam, The Netherlands

e-mail:vannispen@fsw.eur.nl 